\title{
Klossowski's Polytheism: An Introduction to Klossowski's "Nietzsche, Polytheism, and Parody"
}

\section{Russell Ford}

Long recognized as an important and abiding influence in the European artistic and intellectual circles of the last century, the work of Pierre Klossowski is slowly gaining recognition in the Anglo-American scholarly community. ${ }^{1}$ The older brother of the painter Balthus, a friend of Rilke and Gide, and a celebrated artist in his own right, Klossowski is a difficult if not impossible thinker to categorize. From quite early on in his career, Nietzsche was an important influence on Klossowski's work. In addition to translating two volumes for Nietzsche's Oeuvres Complètes $(1967,1976)^{2}$ and Heidegger's four-volume work on Nietzsche (1971), ${ }^{3}$ Klossowski also wrote a number of essays on Nietzsche as well as a book, Nietzsche et le Cercle Vicieux (1969). ${ }^{4}$ In a note to Différence et Répétition, Gilles Deleuze, citing "Nietzsche, Polytheism, and Parody" as well as "Forgetting and Anamnesis in the Lived Experience of the Eternal Return of the Same," writes that Klossowski's work "renewed the interpretation of Nietzsche." 
"Nietzsche, Polytheism, and Parody" is the final essay of Klossowski's book, Un si funeste désir (Such a Deathly Desire), first published in $1963 .{ }^{6}$ It is one of two essays in the book that are devoted explicitly to Nietzsche; the second, "On Some Fundamental Themes of Nietzsche's Gaya Scienza," is the opening essay of the volume and had previously appeared as an introduction to Klossowski's translation of The Gay Science. ${ }^{7}$ "Nietzsche, Polytheism, and Parody" had not previously appeared in print, although Klossowski had presented it as a lecture at the Collège de Philosophie in Paris in 1957. Together, the two essays on Nietzsche bound a series of reflections on Gide, Blanchot, Bataille, and others, all of which appeared previously-sometimes in a different form-and that taken together explicate Klossowski's conception of "the demon." The conception of the demon, drawn from The Gay Science, is for Klossowski a figuration of the double life of the existing human being: both conscious, rational, goal-directed, as well as vital, passionate, a victim of intensities.

One of the chief concerns of Klossowski's work on Nietzsche, including the present essay, is the communicability of Nietzsche's thought.' For Klossowski, the possible communication of this work must be taken up and thought according to the internal logic of Nietzsche's own writingswhich include both his published works and his letters and notes. However, rather than merely seeking to judge the accuracy, appropriateness, or truthfulness of this thoughtall styles of interpretation that would preserve a refuge for the interpreter, a distance from the thought under consideration-Klossowski implicates the interpreter within the interpretation. This is not to say that his work on Nietzsche is an attempt to restate Nietzsche's thought, or to somehow clarify or explain it. Klossowski takes Nietzsche as the bearer or sign of a complex of symptoms, and his essay maps the strategy of this engagement according to the three intertwined elements announced by the title.

To begin with Nietzsche is not to begin with a historically existent being or with an author. As Klossowski 
makes clear by referring to the all-too-recent appropriations of Nietzsche's works (as well as "Nietzschean" concepts and styles) by the Nazis, the word "Nietzsche" is only a mark, a sign. To divide or merely juxtapose the historical individual and the content of the works that bear his name is to ignore the injunctions of both against seeing either as independent of a single experiment. According to this experiment, Nietzsche the professor of philology at Basel gives way to the more audacious figure of the later works (from The Gay Science through the final letters), but then this "visionary" Nietzsche-as Klossowski describes him-gives way, in turn, to the figure of Zarathustra. This double movement repeats the logic of the transformation of the true world into a fable, as described in a famous passage from Twilight of the Idols. ${ }^{10}$ the proposal of the audacious line of thinking by the professor who, as a teacher, is interested in the truth; the impossibility of the actualization of this thought within a teachable form; and the resultant production of the character of Zarathustra, of an "actor," therefore neither truthful nor merely apparent, that follows from the necessary coincidence of thought and its impossibility.

Polytheism seems to be a late topic of the essay, hardly worthy of inclusion in the title. But polytheism is for Klossowski the product of fabulation-the being of the fable-itself the product of the recoil of Nietzsche's thought upon itself, of his notion of fatum. Fatum is the conjunction or synthesis of uttering nonsense ("raving") and prediction; of the moment prior to the creation of meaning and the moment following that meaning's accomplishment. For Klossowski, such a synthesis is effectuated "in the forgetting (of the historical situation) that was preliminary to the act of creating: in forgetting, the past is remembered [sous-vient aे] by humans as their future, which takes the figure of the past." 11 The nonsense of raving is not mere gibberish; it is the utterance of the discontinuity lurking within the individual. As such, it is a type of speaking that forgets its place in time-placement, or order, being what gives any utterance its proper meaning - 


\section{RUSSELL FORD}

and, in losing its place, reveals that place as a moment in which the past comes to determination by being set into an order and thereby given a meaning. Rendered indeterminate by the raving that counters its own utterance, the one who speaks is undercut by the momentum of the vital impulses of the past that sustain but no longer submit to the yoke of the determining consciousness. In raving, the determinate one is rendered into the vital multiple, and this multiplicity is nothing other than the persistence of the past.

The notion of fatum, however, conjoins this vital will to live with the rational will to truth: prediction, the positing of the goal of action. Not only is this antinomy not to be overcome-it cannot be sublated, for Nietzsche or Klossowski-it is itself constitutive of the highest aspiration of thought: the eternal return. How then are the poles of this antinomy conjoined? Pathos, "the unconscious life of impulses," is what raves as consciousness "sub-comes" to its own vitality. But, in reflecting on this vital life, consciousness inverts these very impulses; it forms an image of them as goal-seeking, where the search for a goal is the distinctive mark of conscious willing. Stripping this mark away, "unthinking" consciousness, the impulses are satisfied in what Klossowski calls their "dissipation" [dépense]. This unconscious life is exposed in moments of vital exuberance (of pain or pleasure) whose intensity is grasped only retrospectively and always with the inkling that this remembering is itself a forgetting of the most essential aspect of the experience. In the accomplishments of pathos, of unconscious impulses, the greatest desires of life are satisfied, but these are the very desires that consciousness sets out to fulfill in its search for truth. Consciousness, then, as the impulse or will to stabilize the impulses themselves through the determination of the ends or goals of their activity-and this is the will to truth that foretells, that predicts the constancy that will be satisfaction-in fact wills its dissipation insofar as this dissipation is the accomplishment of the activity (as activity) of vitality. The will to truth engenders fabulation, the 
"necessity" of the reversal of the life of consciousness such that the raving of fatum, which is always apprehended retrospectively, could become the object of prediction. This is the circular law of the eternal return.

Truth as willed error - the law of thought discovered in Nietzsche-is formulated finally as the combative juxtaposition of two gods: "Dionysus versus the Crucified." But this duality is that of the one and the many, not of two distinct unities. Polytheism is the expression of the "raving," vital aspect of existence; "God is dead" expresses a liquidation of the guarantor of identity, and not a simple transfer (to humanity, for instance). Individual existence becomes fragmentary, fortuitous, insofar as it is discovered as the unstable equilibrium of vital and rational forces. In its need for stability, for meaning, and therefore for identity, the individual does not come upon but is swept under by the heterogeneous aspirations of the unconscious impulses that are conjoined with consciousness by chance. Every individual is a perpetual moment-and a perpetuum mobile-of equilibrium, of creation and the reverence that preserves what is created. The world is thus filled with those gods and goddesses (figures of the will to externalization) engendered by this equilibrium, deities with as many forms as there are expressions of vitality: jealous, warlike, loving, wrathful, crafty gods capable of unlimited couplings, combinations and transformations.

Finally, parody. Klossowski cautions at the outset of the essay that no other author seems to lead their interpreter to parody as Nietzsche does. Indeed, what could be more inclined to repetition than a thought that conjoins the will to create and the will to revere-the twin temptations of the interpreter. On the one hand, a will to fill the lacunae, to reconcile the apparent contradictions, to orient and subsume the author's work to a single purpose or thesis. On the other hand, a will to celebrate the insights that ring true and excoriate those that ring false, to prioritize the passages that are, for the interpreter, those that are most deeply affecting, to singularize 


\section{RUSSEIL FORD}

the insights or blunders even as they are repeated, to revere or to condemn (which itself is merely an inversion of reverence) under the guise of critical engagement. The very title of the essay signals Klossowski's acknowledgement of this bind, and his persistence ensures his parody. But this very acknowledgement voids the essay's pretensions to singularity, its own prejudices. It thus concludes with laughter-the voice of an ass, repeated, and serving as the affirmative seal of the pathos implicated within its thesis.

\section{DePaul University}

\section{Notes}

${ }^{1}$ Recently, a number of excellent works on Klossowski have appeared in English. See Ian James, Pierre Klossowski: The Persistence of a Name (Oxford: Legenda, 2001); Eleanor Kaufman, The_Delirium of Praise: Bataille, Blanchot, Deleuze, Foucault, Klossowski (Baltimore: Johns Hopkins University Press, 2001); and Leslie Hill, Bataille, Klossowski, Blanchot: Writing at the Limit (Oxford: Oxford University Press, 2001). For an excellent introduction to Klossowski's thought in French, as well as a detailed bibliography, see Alain Arnaud, Pierre Klossowski, (Paris: Seuil, 1990).

2 See Friedrich Nietzsche, Le Gai Savoir et Fragments posthumes, 1880-1882, trans. Pierre Klossowski (Paris: Club Français du Livre, 1954); reprinted in Oeuvres Completes de Nietzsche, ed. Michel Foucault et Gilles Deleuze (Paris: Gallimard, 1967); and Fragments posthumes 1887-1888, trans. Pierre Klossowski, in Oeuvres Completes de Nietzsche, ed. Michel Foucault et Gilles Deleuze (Paris: Gallimard, 1976).

${ }^{3}$ Published in French as Martin Heidegger, Nietzsche, trans. Pierre Klossowski, 2 vols. (Paris: Gallimard, 1971).

${ }^{4}$ Pierre Klossowski, Nietzsche et le cercle vicieux (Paris: Mercure de France, 1969). English translation: Nietzsche and the Vicious Circle, trans. Daniel W. Smith (Chicago: University of Chicago Press, 1997). When Nietzsche et le Cercle Vicieux was published, Michel Foucault (whom Klossowski considered to be "the best of my interpreters") wrote to the author that "it is the greatest book of philosophy that I have read." See Michel Foucault, Letter to Pierre Klossowski, 3 July 1969, in Cabiers pour un temps (Paris: Centre Georges Pompidou, 1985).

${ }^{5}$ See Gilles Deleuze, Difference and Repetition, trans. Paul Patton (New York: Columbia University Press, 1994), 312n.19. "Forgetting and Anamnesis in the Lived Experience of the Eternal Return of the Same" 


\section{KLOSSOWSKI'S POLYTHEISM}

("Oubli et anamnèse dans l'expérience vécue de l'éternal tetour du Même") was originally published in Nietzsche: Cabiers de Royaumont, Philosophie 6 (Paris: Minuit, 1967), 233-235, and was reprinted in revised form as chapter three of Nietzsche et le cercle vicieux.

${ }^{6}$ Pierre Klossowski, Un si funests désir (Paris: Gallimard, 1963). English translation: Pierre Klossowski, Such a Deathly Desire, trans. Russell Ford (Albany: SUNY Press, forthcoming).

${ }^{7}$ See Pierre Klossowski, "Sur quelques themes fondamentaux de la 'Gaya Scienza' de Nietzsche," in Friedrich Nietzsche, Le Gai Savoir, trans. Pierre Klossowski (Paris: Club Français du Livre, 1954).

${ }^{8}$ See Friedrich Nietzsche, The Gay Science, trans. Walter Kaufmann (New York: Vintage, 1974), Book 4, \$341, 273-274. Klossowski discusses this passage in "On Some Fundamental Themes of Nietzsche's Gaya Scienza."

${ }^{9}$ This concern is not unique to Klossowski; it also figures prominently in the works of Heidegger and Löwith. See Martin Heidegger, Nietzsche, 4 vols., trans. David Farrell Krell (San Francisco: Harper, 1991), and Karl Löwith, Nietzsche's Philosophy of the Eternal Return of the Same, trans. J. Harvey Lomax (Berkeley: University of California Press, 1997).

${ }^{10}$ Friedrich Nietzsche, "How the True World" Finally Became a Fable," in Twilight of the Idols, trans. Walter Kaufmann, in The Portable Nietzsche (New York: Viking Press, 1954), 485-486.

${ }^{11}$ See "Nietzsche, Polytheism, and Parody," below, xx. 